\title{
ENHANCING COGNITIVE FUNCTIONS OF CHILDREN WITH POSTPONED SCHOOL ATTENDANCE
}

\author{
[ROZVOJ KOGNITIVNYCH FUNKCII DETI \\ S ODLOZENOU POVINNOU SKOLSKOU DOCHADZKOU]
}

\author{
Zuzana Babulicova
}

\author{
doi: 10.18355/PG.2016.5.1.143-161
}

\begin{abstract}
In the present paper we describe and analyze the issue of cognitive functions and structural cognitive modifiability. In the empirical level we present the results of application of the cognitive educational programme in order to develop (address deficit) cognitive functions of children with postponed compulsory school attendance.
\end{abstract}

\section{Key words}

structural cognitive modifiability, cognitive function, deficit cognitive function

\section{Anotácia}

V predkladanom príspevku v teoretickej rovine popisujeme a analyzujeme problematiku kognitívnych funkcií a štrukturálnej kognitívnej modifikovatel'nosti. V empirickej rovine prezentujeme výsledky aplikácie programu kognitívnej edukácie s ciel’om rozvoja (nápravy deficitných) kognitívnych funkcií detí s odloženou povinnu školskou dochádzkou.

\section{Kl’účové slová}

štrukturálna kognitívna modifikovatel'ost', kognitívne funkcie, deficity kognitívnych funkcií

\section{Úvod}

Existencia jednotlivca v prostredí (vnútorné i vonkajšie) si vyžaduje, aby sa prostrediu a jeho podmienkam prispôsoboval, čo znamená, že od jednotlivca je očakávané, že bude sám seba modifikovat'. Modifikovatel'nost' takto možno chápat' ako adaptáciu. Jednotlivec sa v priebehu svojho života prispôsobuje a tým sa mení, napríklad zmena v kognitívnych schopnostiach, zrenie organizmu (starnutie).

\section{Kognitívna modifikovatel'nost'}

R. Feuerstein vysvetl'uje zmeny v kognitívnych schopnostiach jednotlivca ako teóriu štrukturálnej kognitívnej modifikovatel'nosti, ktorú stavia na presvedčení, že jednotlivec má v sebe prirodzenú tendenciu menit’ sa a má schopnost' prispôsobovat' sa prostrediu. Jednotlivec je schopný sám seba modifikovat' bez ohl'adu na vek, či iné determinanty aktuálneho stavu jednotlivca, pričom jeho limity nie sú dané. Zmeny, ktoré v kognitívnom 
vývine jednotlivca nastávajú nemôžu byt' vysvetl’ované iba na základe dedičnosti, či vrodených faktorov, ale ani izolovane ako zmeny vyvolané determinantmi z prostredia. Napríklad, rovnaký učebný štýl nepreferujú všetci jednotlivci pochádzajúci z rovnakého sociálneho prostredia (kultúry), ani všetci jednotlivci, ktorí sú na približne rovnakej kognitívnej úrovni a na stimuly z prostredia môžu reagovat' úplne odlišne, niekedy neprimerane.

Neprimeraná reakcia na stimul, ktorý prichádza z kultúrneho prostredia má mnoho podôb. Neprimerané reakcie na podnety z prostredia sa neprejavujú len kultúrnou odlišnost'ou, ale môžu variovat' ako etnické, socioekonomické, profesijné i mentálne odlišnosti. R. Feuerstein (2006) hovorí o kultúrnej deprivácii ako o nedostatku skúsenosti sprostredkovania. Tento nedostatok je ovplyvnený exogénnymi činitel'mi, akými sú napríklad kultúrne podmienky, v ktorých neprichádza $\mathrm{k}$ sprostredkovaniu, prípadne podmienky, $\mathrm{v}$ ktorých $\mathrm{k}$ sprostredkovaniu dochádza, ale to nemá dostatočnú intenzitu a kvalitu na to, aby modifikovalo mentálny systém jednotlivca, čo môže byt' spôsobené aj endogénnymi psychickými danost'ami.

Pozitívna zmena $v$ štruktúre myslenia jednotlivca vplyvom sprostredkovania predstavuje snahu modifikovat' jeho kognitívnu kapacitu. Ako východisko však pre nás musí slúžit' skutočnost', že inteligencia nie je fixná, ale je možné modifikovat' ju. Sprostredkujúca intervencia predstavuje optimálny a efektívny spôsob, ako modifikovat' inteligenciu jednotlivca, teda jeho kognitívne funkcie a myslenie). Táto premisa vychádza z teórie R. Feuersteina (tamtiež), ktorý d'alej vysvetl'uje, že modifikovatel'nost' je vlastnost' ludského intelektu, prejavuje sa v spojitosti so špecifickými formami interakcie medzi jednotlivcom a prostredím, v ktorom žije.

\section{Model kognitívnych funkcií A. R. Luriju}

Činnost' zameraná na rozvoj kognitívnych funkcií sa stáva kognitívnou edukáciou, ak je založená na systematickej edukácii jednotlivca, aby sa naučil reflektovat' na požiadavky, ktoré zahŕňajú kognitívne funkcie: pamät', pozornost', posudzovanie, jazyk a vnímanie, znázorňovanie a predstavy.

A.R. Lurija (in Pokorna, 2010c: 98) vytvoril model, ktorého štruktúru určujú tri funkčné jednotky:

a) systém vstupu (input) - obsahuje nasledovné funkcie: prijímanie informácií, analýza informácií a uchovávanie informácií. Prevažne ide o funkcie vnímania a pamäti;

b) systém výstupu (output) - je charakterizovaný nasledovnými funkciami - programovanie činnosti, regulácia činnosti a vykonávanie činnosti $\mathrm{v}$ závislosti na informáciách zo systému vstupu. Output je spätne kontrolovaný vnímaním, ktoré je súčastou input systému

c) systém aktivácie a vedomia - má nasledovné úlohy:

1. aktivovat' celý systém;

2. zabezpečit' vedomý priebeh celého procesu.

Informácie sú v tomto systéme vyhodnocované, zároveň však treba zdôraznit', že do spracovávania informácií vstupujú primárne (biologické) a sekundárne (individualizované) motívy. To znamená, že na spracovávaní jednotlivých vzruchov podielajú na 
biologickej úrovni vrodené inštinkty, obranné a reakcie a pod. a na individualizovanej úrovni naše skúsenosti, ale i emócie a motivácia $\mathrm{k}$ činnosti.

Ako uvádza A. R. Lurija „l’udský mozog je konštituovaný základnými funkčnými jednotkami, ktoré sú ako jednotka ovládania napätia a bdelosti, ako jednotka prijatia, spracovania a zapamätávania informácií, ktoré prichádzajú z vonkajšieho sveta a ako jednotka programovania, ovládania a kontroly psychickej činnosti““ (in Pokorna, 2010c: 98).

\section{Kognitívne funkcie a deficity kognitívnych funkcií podl'a $R$. Feuersteina}

Model kognitívnych funkcií podl’a R. Feuersteina nadväzuje na vy̌šie charakterizovaný model kognitívnych funkcií A. R. Luriju. R. Feuerstein však A. R. Lurijov model zjednodušuje. Uvedomuje si prepojenost' jednotlivých úrovní, ale radí ich zásadne v sekvencii input (vstup) elaborácia (spracovanie)- output (výstup). R. Feuerstein pritom elaboráciu chápe ako schopnost' vedome pracovat' $\mathrm{s}$ myšlienkovými operáciami $(\mathrm{v}$ porovnaní so systémom aktivácie a vedomia v predchádzajúcom vymedzení).

R. Feuerstein, Y. Rand et al. (1980) bližšie kategorizovali kognitívne funkcie, ktoré sú v procese kognitívnej edukácie rozvíjané. Ako sme už uvideli po vzore A. R. Luriju menovaní autori vymedzili jednotlivé kognitívne funkcie, ktoré sú prítomné a rozvíjané vo fáze prijímania a získavania informácií (input), vo fáze spracovania informácií (elaborácia) a vo fáze riešenia problémov a formulovania riešení. V každej úrovni kognitívneho spracovania sú jednotlivé kognitívne funkcie priradené na základe ich prítomnosti $\mathrm{v}$ jednotlivých štádiách spracovávania informácií, zapracovávania nadobudnutých poznatkov do vedomostnej štruktúry, resp. nadobúdania nových skúseností.

Deficity kognitívnych funkcií podla R. Feuersteina sú deficity tých funkcií, ktoré tvoria základ internalizovaného, reprezentačného a operačného myslenia. Tieto funkcie nemožno zamieňat' s operáciami, alebo obsahmi myslenia ako celku, pričom zdôrazňuje, že deficity kognitívnych funkcií nie je možné chápat' ako nemennú charakteristiku jednotlivca, ale skôr ako spôsob jeho interakciu sučebnými problémami a úlohami, ktoré sú z nejakého dôvodu nevhodné.

Kognitívne funkcie môžu byt' narušené $z$ rôznych dôvodov. Podl'a R. Feuerstein (2006) kognitívne funkcie môže obmedzit' narušenie procesu sprostredkovania zo staršej generácie na mladšiu generáciu a to v každej kultúre, vnútorné príčiny, alebo deprivácia (nedostatočná skúsenost' sprostredkovaného učenia).

Pri hl’adaní príčin deficitov a problémov v kognitívnom vývine jednotlivca, teda problémy na úrovni kognitívno - emocionálno - motivačných predpokladov pre optimálne formy adaptácie R. Feuerstein (1980) rozlišuje nasledovné faktory kognitívneho vývinu: 
- distálne faktory - genetické faktory (vrodené abnormality), nevyrovnaný vývin kognitívnych funkcií, príslušnost' ku kultúre odlišnej skupiny, podnetnost' prostredia, socioekonomický status, emocionálne problémy rodičov, alebo diet'at'a, organické poškodenie ai. - R. Feuerstein vysvetl'uje, že tieto faktory môžu, ale nemusia viest' $\mathrm{k}$ abnormálnemu alebo problematickému vývinu kognitívnych funkcií;

- proximálne faktory - napr. skúsenost' sprostredkovaného učenia, môžu mat' vo rozvoji kognitívnych funkcií klúčcovú úlohu a ich nedostatok alebo absencia vytvára:

- stav kultúrnej deprivácie (resp. kultúrneho handicapu);

- deficity vo vývine kognitívnych funkcií (in Malkova, 2008).

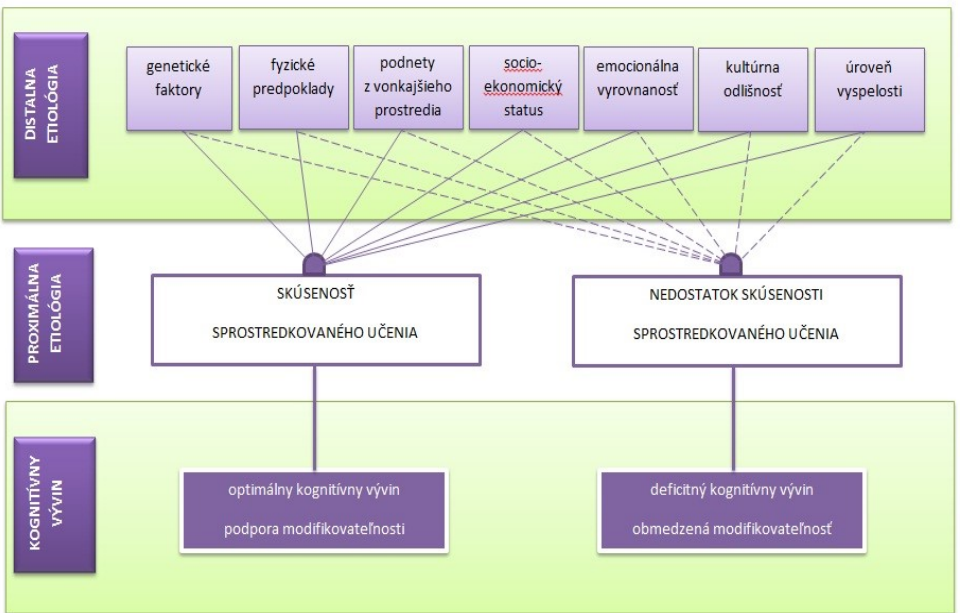

Obrázok 1 Distálne a proximálne vplyvy vo vývine kognitívnych funkcií (Zdroj: Feuerstein, R. a kol. 1980)

J. Duchovičová (Duchovicova, 2011) dopĺn̆a, že R. Feuerstein a mnoho d’alších odborníkov, ako radikálni optimisti zastávajú názor, že kognícia je modifikovatel'ná, no základom zmeny je viera, že diet’a sa môže menit'. Pre človeka je prirodzená tendencia ku zmene a schopnost' prispôsobovat' sa okolitému prostrediu. Limity učenia nie sú a priori známe (vyjadritel’né napr. IQ). Všetci l'udia sú otvorené systémy, ktoré majú šancu prejst' zmysluplnou štrukturálnou zmenou $\mathrm{v}$ priebehu svojho života, pričom zdôrazňuje, že modifikovatel'nost' je možná bez ohl'adu na vek, etiológiu súčasného stavu a vážnost' genetických, fyzických alebo psychologických defektov.

R. Feuerstein (2006) považuje modifikovatel'nost' a rozmanitost', ktorá sa odvíja od prítomnosti a kvality sprostredkujúcich interakcií v priebehu (kognitívneho) vývinu jednotlivca za základné predpoklady jeho adaptácie na podmienky určované jeho endogénnym a exogénnym prostredím.

Základné teoretické východisko sprostredkovaného učenia teda tvorí teória štrukturálnej kognitívnej modifikovatel'nosti. Ak si uvedomíme, že inteligencia nie je fixná, ale dá sa menit' sme ochotní prijat' túto premisu. 
Prostredníctvom sprostredkovanej intervencie možno modifikovat' inteligenciu (myslenie a štruktúru kognitívnych funkcií jednotlivca). Skutočnost', že sprostredkované učenie umožňuje vytváranie kognitívnych funkcií ako predpokladov pre neskoršie nezávislé učenie potvrdzujú realizované výskumy R. Feuersteina, S. Kleina, A. J. Tannenbauma (1991), A. Kozulina (1994), J. Leebera (1994) a d'alších. Hlavný ciel' programu inštrumentálne obohacovania je vedenie jednotlivca ku kvalitnejšiemu a samostatnejšiemu učeniu v snahe dosiahnut' modifikáciu (deficitov) jeho kognitívnych funkcií. R. Feuerstein vypracoval intervenčný program inštrumentálneho obohacovania zameraný na rozvoj kognitívnych funkcií jednotlivca sprostredkujúcim prístupom, ktorý sme implementovali pri edukácii detí s odložanou povinnou školskou dochádzkou v podmienkach bežnej materskej školy.

\section{Metodologické východiská výskumu}

Ciel'om realizovaného výskumného šetrenia bolo sledovat' a popísat' zmeny v kognitívnych funkciách detí s odloženou povinnou školskou dochádzkou, ktoré budú determinované aplikáciou intervenčného programu kognitívnej edukácie R. Feuersteina. V snahe hlbšieho pochopenia zmien $\mathrm{v}$ kognitívnych funkciách detí s odloženou povinnou školskou dochádzkou a so zretel'om sledovania dynamiky ich rozvoja sme využili metódu kváziexperimentu. Výskumnú vzorku sme vytvorili zámerným výberom. Po konzultácii

s odborníkmi z Centra pedagogicko-psychologického poradenstva a prevencie $\mathrm{v}$ Nitre, ktorí nám odporučili materské školy, kde boli zaradené deti s diagnostikovanými deficitmi kognitívnych funkcií, deti s odloženým nástupom školskej dochádzky. Do experimentálnej skupiny bolo zaradených šest' detí, ktoré boli v prostredí svojej materskej školy účastné programu inštrumentálneho obohacovania a všetkých výchovnovzdelávacích aktivít materskej školy vzhl'adom na jej možnosti a platnú legislatívu.

Upravený denník lektorky programu slúžil na prípravu a následné vyhodnocovanie jednotlivých stretnutí, kde sme pracovali $\mathrm{s}$ vybranými inštrumentmi programu. Jednotlivé denníky boli vyhodnocované len pre experimentálny skupinu. Preto považujeme za dôležité uviest', že z metodologického hl'adiska ide o metódu kváziexperimentu, pretože sme účinnost' experimentálneho zásahu sledovali len vjednej (v experimentálnej) skupine. Sledovali sme nielen počiatočný a konečný stav (úroveň), ale aj dynamiku sledovaných faktorov v priebehu celého experimentálneho overovania účinnosti programu.

1. Denník lektorky programu - ako lektori programu inštrumentálneho obohacovania R. Feuesteina sme si viedli denník $v$ podobe záznamových hárkov pre prácu s jednotlivcom po každom sedení. Záznamový hárok bol vypracovaný V. Pokornou, ktorý slúži najmä ako príprava lektora na lekciu a následne jej hodnotenie, kde si lektor všíma najmä zmeny, ktoré nastali v kognitívnych funkciách. Pre potreby nášho výskumu (pre

Slavonic Pedagogical Studies Journal, ISSN 1339-866o, Volume 5 Issue 1, February 2016 
prácu s inštrumentmi s det'mi s odkladom povinnej školskej dochádzky) sme vytvorili záznamové hárky $\mathrm{v}$ podobe numerických intervalových škál pre jednotlivé faktory, aby sme zachytili intenzitu sledovaných faktorov pre možné sledovanie nielen ich kvantitatívneho nárastu (event. poklesu), ale rovnako, aby sme zachytili ich dynamiku v priebehu šetrenia.

Sledovali sme nasledovné kognitívne funkcie:

- impulzivitu diet'at’a pri riešení úloh;

- úroveň jeho verbalizácie postupov riešených úloh;

- prekonávanie problémov diet'at'a v percepčnej oblasti;

- a prácu s premostením.

Práca s det'mi experimentálnej skupiny prostredníctvom programu inštrumentálneho obohacovania R. Feuersteina- základný sprostredkujúcim učením prebiehala počas celého školského roka. V priestoroch materskej školy sme pracovali so šiestimi det'mi, ktoré mali odklad povinnej školskej dochádzky. S det'mi sme pracovali dva krát týždenne po 60 minút.

Rozsah nami navrhnutej numerickej intervalovej škály bol 0 až 9 , pričom 0 znamenala, že diet’a sa stretnutia nezúčastnilo (v grafe neuvádzame), 1 vyjadrovala najnižšiu intenzitu sledovaného javu vo výkone (v prejave) konkrétneho diet'at'a a 9 najvyššiu intenzitu sledovaného javu. Záznamové archy sme spracovávali pre jednotlivcov (nie pre skupinu ako celok) a zaznamenané výsledky sme spracovali do podoby grafov.

\section{Graf 1 Veronika - impulzivita pri riešení úloh}

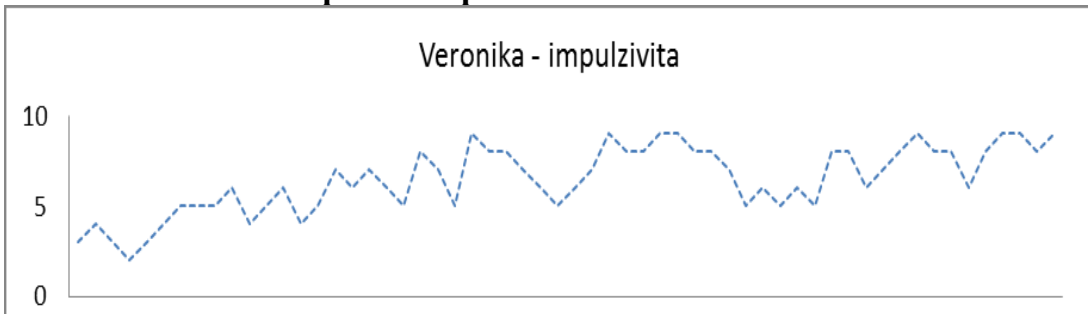

135579111315171921232527293133353739414345474951535557

\section{Graf 2 Veronika - úroveň verbalizácie postupov riešených úloh}

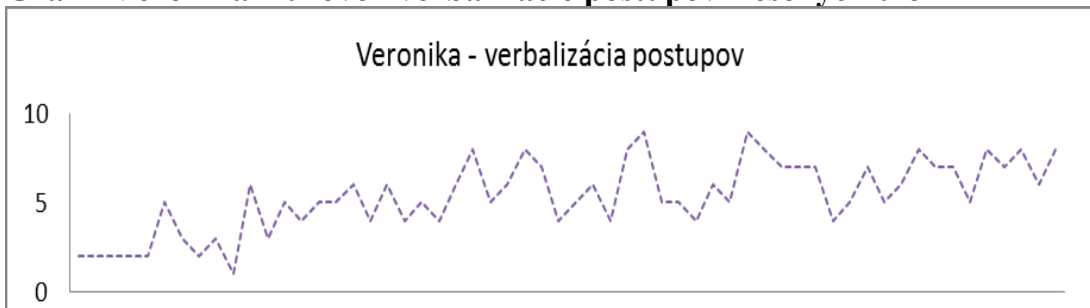

1335799111315171921232527293133353739414345474951535557 


\section{Graf 3 Veronika - prekonávanie problémov v percepčnej oblasti}

Veronika - prekonávanie problémov

10

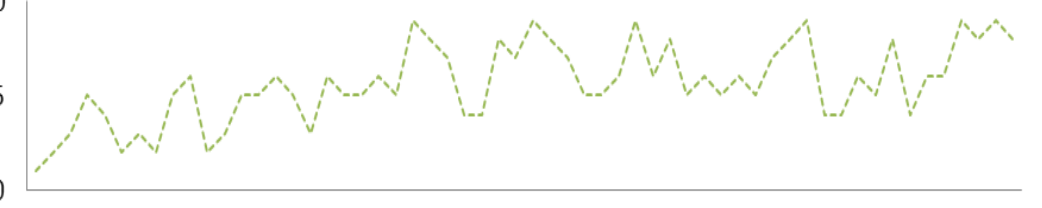

13579111315171921232527293133353739414345474951535557

\section{Graf 4 Veronika - práca s premostením}

Veronika - práca s premostením

10

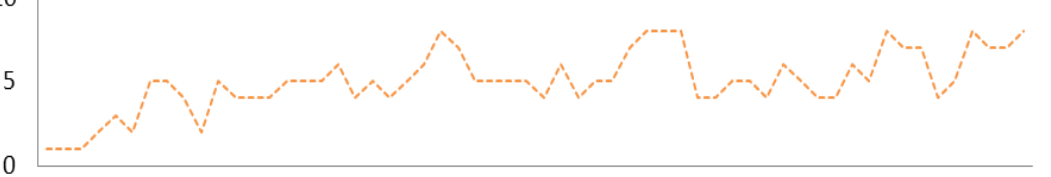

13557790111315171921232527293133353739414345474951535557

Veronika bola na začiatku našej práce vel'mi utiahnutá. Jej reakcie na podnety boli pokojné. Pri akejkol’vek činnosti bola nesamostatná, čo sa prejavovalo v pasivite pri riešení úloh. Spoliehala sa na ostatné deti a vždy čakala, aby názor, prípadne riešenie prezentovali najskôr deti a ona sa vždy pridala k poslednému vyjadrenému názoru (zo začiatku sa názory (riešenia) detí opakovali, pretože deti na začiatku našej práce nespolupracovali. Na akúkol'vek položenú otázku odpovedali všetci naraz, na našu požiadavku, komunikácie založenej na vzájomnom počúvaní sa, deti postupne vyjadrovali svoje myšlienky, nasledujúce diet’a však opakovalo myšlienky predchádzajúceho diet'at'a, čo však nebolo naším zámerom. S Veronikou sme v tomto ohl'ade dlho pracovali na vyjadrovaní vlastných myšlienok, aby sa nebála svoj postoj (riešenie) prezentovat'. Vzhl'adom k osobitostiam predškolského veku sme ešte nemohli hovorit' o diskusii, pretože deti nekomunikovali navzájom, ale viedli dialóg s nami. Ich myšlienky vzájomne na seba nenadväzovali. Uvedomovali si stanovené pravidlá práce na stretnutiach, napr. o neskákaní si do reči, chápali to však ak podmienku, že musia počkat', kým iné diet'a dohovorí a potom vyjadrit' svoj názor bez ohl'adu na to, čo povedalo iné diet'a predtým. Postupne nastala zmena v tom, že deti počúvali jeden druhého, ale ak mali protiargumenty adresovali ich nám a nie diet’at’a, ktorú danú myšlienku vyslovilo (,,pani učitel'ka, ale to nie je pravda....").

Veronika vzhl'adom k pomalému tempu práce nepracovala impulzívne, nad riešeniami však nepremýšl’ala. Počas činnosti „opisovala“ od ostatných detí (metodika práce nezakazovala). My sme však Veroniku povzbudzovali 
k samostatnosti. V priebehu práce Veronika nadobúdala odvahu, že úlohy môže riešit' aj sama, a však začala riešit' úlohy impulzívne, teda prvé čo ju napadlo. Ako znázorn̆uje graf, impulzivita a unáhlené riešenia sa $\mathrm{z}$ práce postupne vytrácali, čo bolo spojené aj so zvyšujúcou sa úrovňou verbalizácie postupov práce. Veronika sa pri verbalizovaní postupu práce viac sústredila na samotný proces riešenia a sama sa dokázala často opravit', resp. nájst' chybu a zdôvodnit', prečo mohla nastat'.

Najvýraznejšie výkyvy boli v zložke prekonávanie problémov, tým že si Veronika neverila, pri náročnejších úlohách strácala motiváciu a prácu často nechcela dokončit'. V spojitosti s predchádzajúcim sledovaným faktorom bolo jednoduché pri verbalizácii postupov riešenia určit', kedy sa Veronika vzdala a v riešení nepokračovala, ale radšej požiadala iné diet’a, aby jej riešenie ukázal, čo sme i napriek nevyriešenej úlohe mohli považovat' za pozitívny krok, nakol'ko na začiatku školského roka Veronika nikdy iné deti neoslovovala, výhradne len lektorku. Práca s premost’ovaním bola v prípade ak mala Veronika osobnú skúsenost' dobrá, k neznámym situáciám sa nevyjadrovala.

\section{Graf 5 Lukáško - impulzivita pri riešení úloh}

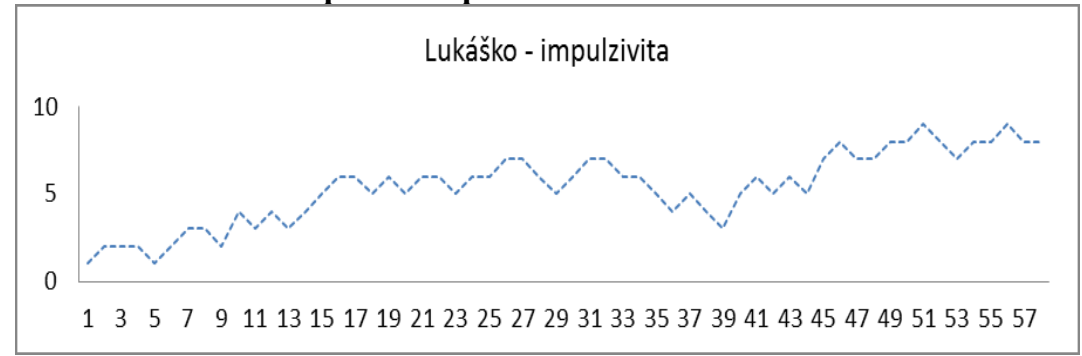

Graf 6 Lukáško - úroveň verbalizácie postupov riešených úloh

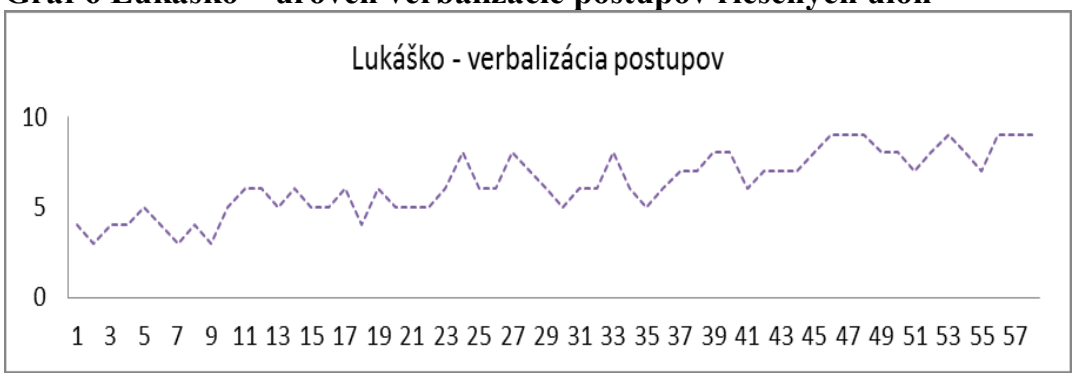




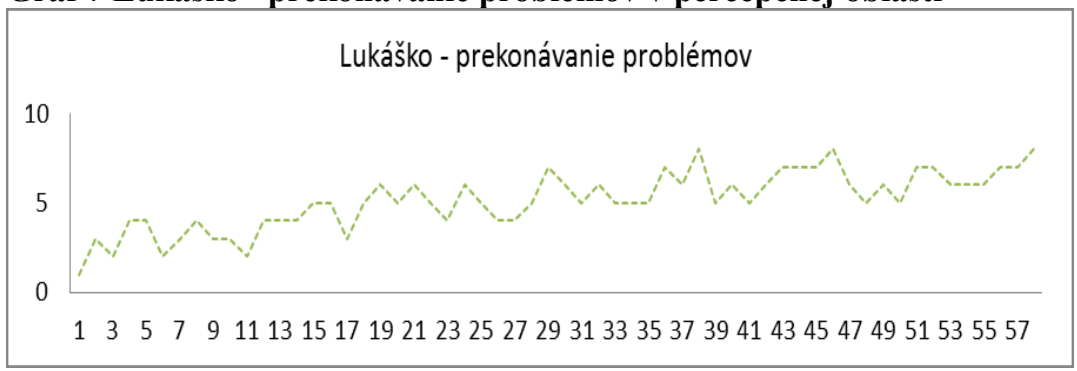

\section{Graf 8 Lukáško - práca s premostením}

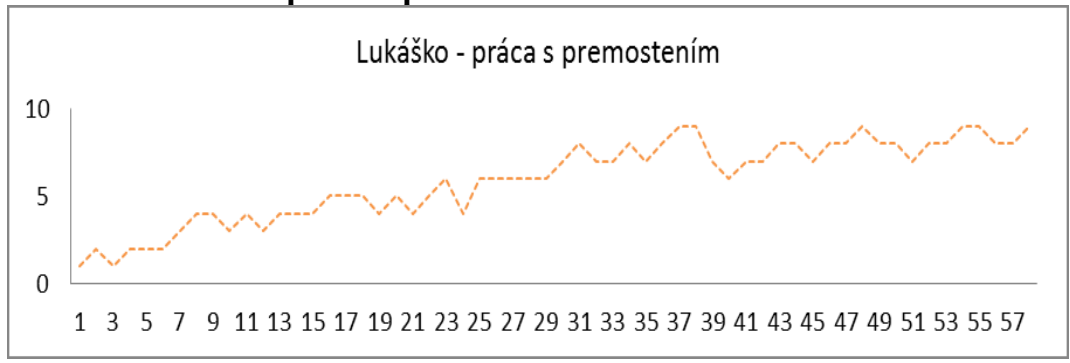

Na začiatku školského roka bol Lukáško vodca a hovorca celej skupiny. Najvýraznejšie a najčastejšie sa zapájal do práce. Často sa pokúšal organizovat' celú skupinu, tak aby robila to, čo on práve chcel. Lukáško bol vel'mi otvorený a komunikatívny. Pri riešení úloh bol však vel'mi rýchly a ak nevedel $\mathrm{v}$ inštrumente usporiadanie bodov nájst' riešenie vhl'adom, skôr ako by uvažoval nad zadaním jednotlivých úloh ich vyriešil postupom pokus - omyl. Často tak v inštrumentoch prečiarkoval, prípadne gumoval, čo mu však zabralo vel'a času a tak vyžadoval od ostatných detí, aby prerušili prácu a čakali, kým on (popredu) vyrieši úlohu, aby im mohol ukázat’ riešenie.

Ako je $\mathrm{v}$ grafe vyjadrujúcom Lukáškovu impulzivitu pri riešení úloh vidiet', zo začiatku Lukáško pracoval výlučne impulzívne. Nečakal na zadanie inštrukcií, ani ich odvodenie, ale kým nemala vyriešenú úlohu, nevnímal, čo sa okolo neho deje. Pri ovládaní jeho impulzivity nám výrazne pomohol manipulatívny inštrument zameranie pozornosti na tri zdroje učenia. Ako sme už uviedli bol zameraný na sústredené manipulovanie so skrytým predmetom. Lukáško sa učil, že pracovat' môžeme aj pomaly a sú úlohy, ktoré si presnú (niekedy pomalú) prácu vyžadujú.

Pri verbalizácii postupov Lukáško nemal výrazné problémy, nakol'ko bol komunikatívny a otvorený mal bohatú slovnú zásobu a bol zvyknutý vysvetl'ovat' postup práce. Problém bol prekonat' jeho predstavu, že ak nevedel riešenie okamžite, tak si myslel, že nie je dost' dobrý na to, aby danú úlohu vyriešil.

V nadväznosti na uvedenú skutočnost' je tiež $v$ grafe prekonávanie problémov v percepčnej oblasti vidiet', že počas našich stretnutí hodnota tohto sledovaného faktoru kolísala. Problém nastal pri náročnejších úlohách, 
ktoré si vyžadovali prípravu, prípadne dlhší pracovný postup, pretože ak Lukáško nevidel výsledok svojej práce hned', vel’mi rýchlo strácal motiváciu $\mathrm{k}$ dokončeniu úlohy.

Najvýraznejší problém sme zaznamenali pri stránkach inštrumentu usporiadanie bodov, kde sa pracuje s chybou. Lukáško bol ochotný identifikovat' chybu, ale nechcel ju opravovat'. Lukáško bol presvedčený, že ak už sme raz úlohu riešili a výsledok sme dosiahli, bez ohl'adu na to, či riešenie a výsledok sú správne netreba sa úlohou viac zaoberat', ved' predsa už je vyriešená.

Istý paradox sme potom sledovali pri premostovaní, kedy Lukáško uvádzal množstvo príkladov, kedy a prečo je dôležité kontrolovat' svoju prácu, nielen výsledok, ale aj postup riešenia. Vyslovené situácie a príklady boli správne, Lukáško však nevedel akú majú uvedené príklady spojitost's jeho názorom, že vyriešenej úlohe sa netreba venovat'.

\section{Graf 9 Simonka - impulzivita pri riešení úloh}

Simonka - impulzivita

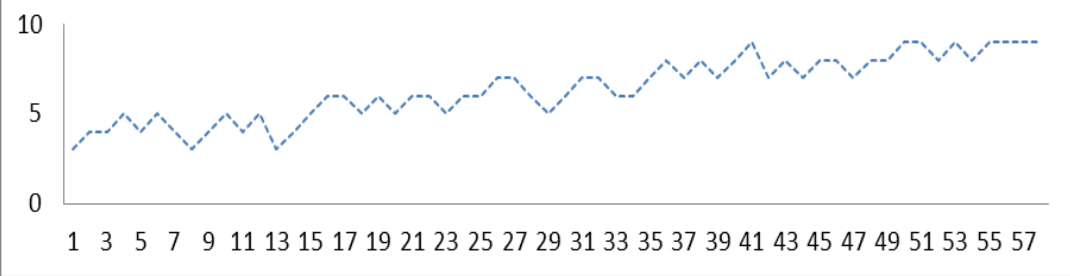

Graf 10 Simonka - úroveň verbalizácie postupov riešených úloh

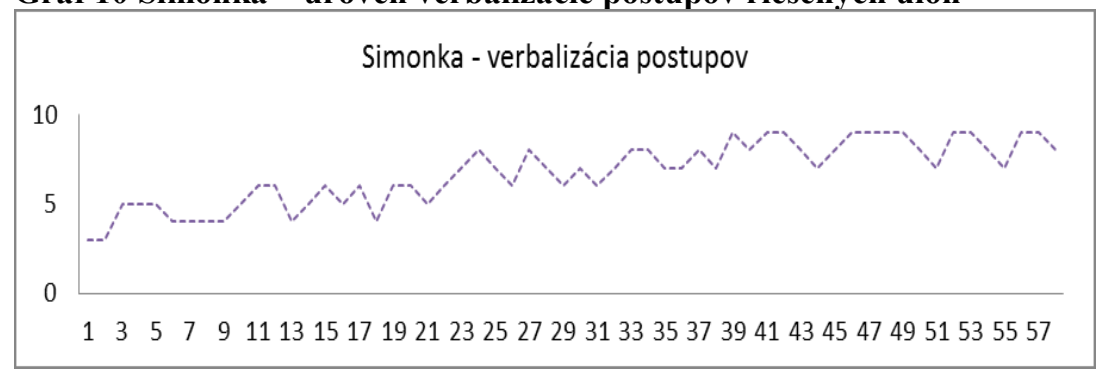

Graf 11 Simonka - prekonávanie problémov v percepčnej oblasti

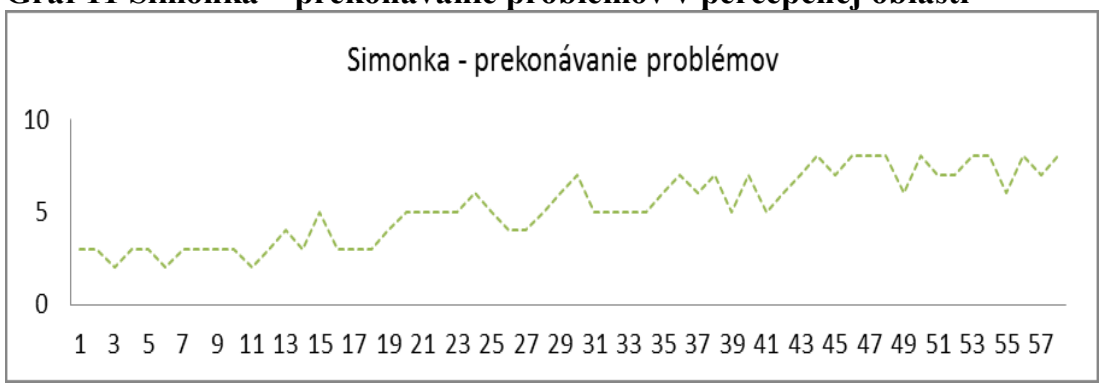


Graf 12 Simonka - práca s premostením

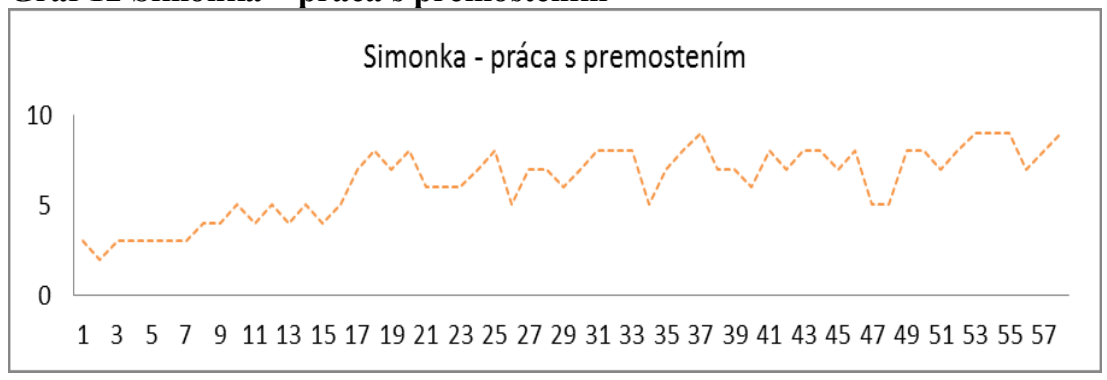

Simonka už na začiatku našej práce bola po kognitívnej stránke pripravená na vstup do školy. Pre odklad nástupu na povinnú školskú dochádzku sa Simonkini rodičia rozhodli kvôli jej nižšiemu vzrastu a podl'a ich názoru nízkej sebadôvere, ktorú Simonka mala.

Pri práci s nami bola Simonka pozorná, koncentrovaná a čakala na pokyny. Z tohto hl'adiska by sme mohli konštatovat', že bola nesamostatná. Simonka však nemala súrodencov a bola zvyknutá trávit’ čas najmä v kruhu svojej rodiny, teda dospelých l'udí. Každý deň ju z materskej školy vyzdvihovala stará mama, ktorá $\mathrm{s}$ ňou trávila čas do večerných hodín, kým sa rodičia vrátili z práce. Medzi det'mi v skupine bola Simonka spočiatku utiahnutá, nakol'ko z jej kmeňovej triedy do skupiny nepatrilo žiadne iné diet’a. Približne po mesiaci sa však Simonka skamarátila so Sofiou a to jej dodalo odvahu a motiváciu pre prácu na našich stretnutiach.

Simonka nemala žiadne výraznejšie problémy pri práci s inštrumentmi. Pri prvom inštrumente sme sa u Simonky zamerali najmä na jej uchopenie a vnímanie geometrických tvarov, nakol'ko mala problém s diskrimináciou geometrických tvarov. V priebehu práce si však Simonka zvnútornila základné vlastnosti (charakteristiky) vybraných geometrických tvarov, vedela ich pomenovat' a správne jednotlivé charakteristiky konkrétnych predmetov (obrazcov) i uchovat', čo sa preukázalo i v jednotlivých úlohách inštrumentu zameranie pozornosti na tri zdroje učenia, kde Simonka nielen presne prenášala (zakresl’ovala) predmety na papier, ale vždy ich aj správne pomenovala.

Simonka od začiatku pracovala koncentrovane a preto nebol výrazný problém s ovládaním jej impulzivity. Simonka sa nebála riešit' i náročnejšie úlohy, pričom ak mala problém požiadala najskôr Sofiu, prípadne skupinu, aby jej pomohli.

Ako sme už uvideli, Simonka nemala problém s pomenovávaním jednotlivých pojmov. V priebehu našich stretnutí spoznala bližšie jednotlivých členov skupiny, s ktorými sa skamarátila na v skupine sa potom nebála prejavovat' názory. Verbalizácia postupov riešenia bola u Simonky už v počiatku na dobrej úrovni, ako je však z grafu zrejmé, už v druhej tretine našich stretnutí sa úroveň tejto zložky významne zvýšila.

Najmä pri práci s inštrumentom zameraným na rozpoznávanie emócií Simonka vel'mi presne pomenovávala jednotlivé emócie. Ked' Simonka jednotlivých členov skupiny ešte nepoznala pozorovala ich pri práci. Po

Slavonic Pedagogical Studies Journal, ISSN 1339-8660, Volume 5 Issue 1, February 2016 
zoznámení sa, si s det'mi vybudovala blízky vzt’ah, často pomenovávala náladu, prípadne emócie ostatných detí. Práca s premostením bola u Simonky na výbornej úrovni.

\section{Graf 13 Sofia - impulzivita pri riešení úloh}

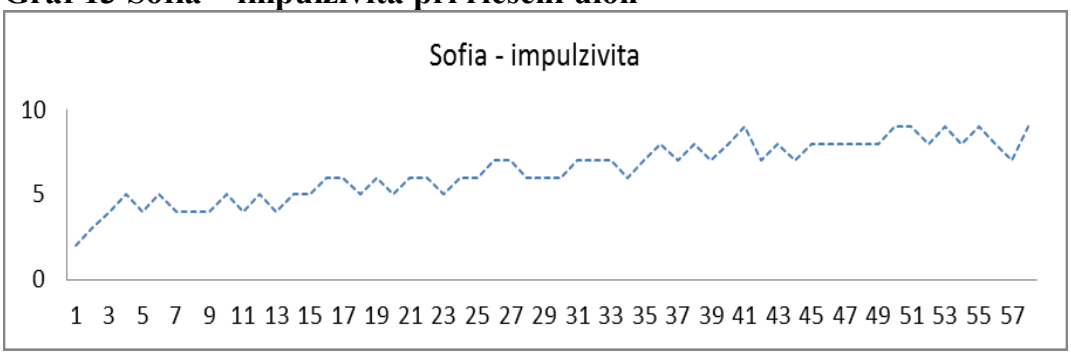

Graf 14 Sofia - úroveň verbalizácie postupov riešených úloh

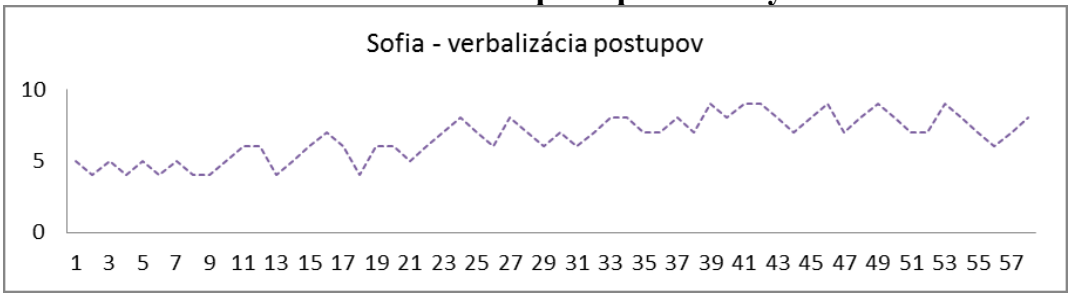

Graf 15 Sofia - prekonávanie problémov v percepčnej oblasti

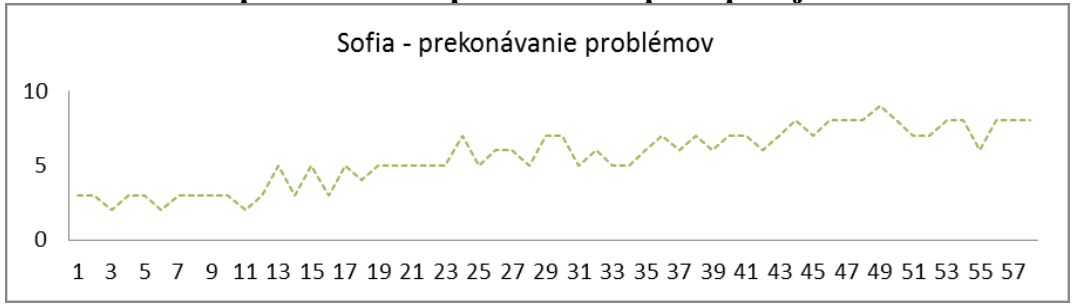

Graf 16 Sofia - práca s premostením

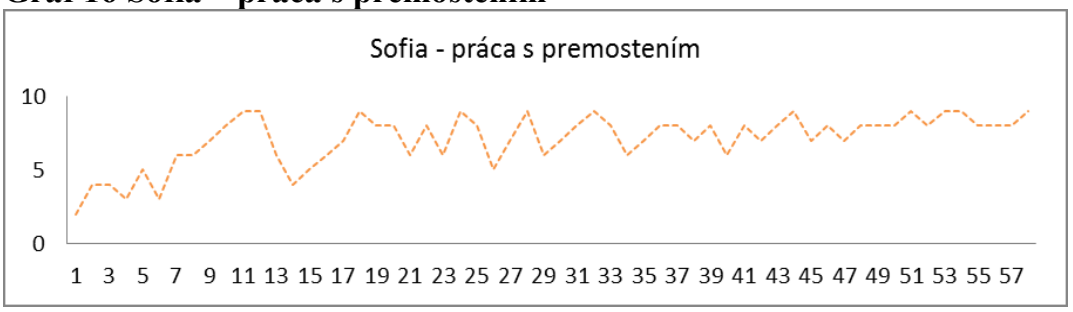

Sofia bola už od začiatku našej práce vel'mi samostatná. Mala vel'kú zál'ubu v kreslení a spočiatku sa dožadovala, aby sme na stretnutiach pracovali s farebnými ceruzkami, aby boli naše kresby veselšie. Sofiina práca bola úhl'adná, na svoju prácu sa koncentrovala a ako formu kontroly svojej práce ako jediná v skupine nežiadala o hodnotenie nás, ale vždy si svoju kresbu skontrolovala (prirovnala) k ostatným det'om. 
Napríklad pri kreslení postavy a zvierata si výslednú kresbu porovnala (len vizuálne) so Simonkinou kresbou. Simonka svojej postave dievčat’a a aj na kresbe zvierat'a (psa) doplnila mašl'u do vlasov, psovi na hlavu, potom doplnila dievčatu aj náhrdelník. Tak aj Sofia svoju kresbu doplnila a svojej postave nakreslila náhrdelník tiež.

Sofia pri riešení jednotlivých úloh nebola impulzívna, jej pracovné tempo bolo optimálne a čakala na všetky inštrukcie. Ak inštrukcia nebola zadaná, čakala na pokyny, prípadne sa spýtala, čo má robit', ak bola požiadaná o vytvorenie inštrukcie urobila to. Pracovat' (riešit' úlohy) začínala medzi poslednými, nakol'ko vždy najskôr pozorovala, čo budú robit' ostatné deti. Práca $s$ inštrumentom zameranie pozornosti na tri zdroje učenia Sofiu vel'mi bavili a povedala, že je rada, že všetci čakajú ako to ona urobí a nikto jej nehovorí, aby pracovala rýchlo. Práca sa jej páčila. Môžeme konštatovat', že Sofia sa dokázala sústredit' na zadanú úlohu dostatočne dlho na to, aby verne zobrazila predmet, ktorý mala zakreslit'. Ostatné deti boli väčšinou zvedavé aký predmet sa $\mathrm{v}$ škatuli nachádza a tak hned' potom čo s ním manipulovali ho nakreslili (bez detailov) a pozreli sa ako vyzerá v skutočnosti. Sofia však svoju impulzivitu natol'ko ovládala, že viackrát opätovne striedala manipuláciu s predmetom a jeho zakresl'ovanie (diet'a manipuluje spredmetom, bez toho, aby sa naň pozrelo ho zakreslí, $\mathrm{v}$ prípade, ak si nie je istý, prípadne si chce kresbu zdokonalit', prípadne skontrolovat', môže opät' vložit' ruky do škatule a manipulovat' $\mathrm{s}$ predmetom).

Aj na základe práce suvedeným inštrumentom i ostatnými, najmä orientácia $\mathrm{v}$ priestore sa postupne u Sofii zdokonalovalo prekonávanie problémov v percepčnej oblasti Sofia mala problém so zachovaním stálosti (geometrických) objektov ak sa otáčali. Pri jednotlivých stretnutiach Sofia trvala na tom, že pri vypracovávaní úloh $\mathrm{v}$ jednotlivých inštrumentoch, prípadne d’alších úloh chcela vždy sediet' vedl'a nás (aj napriek tomu, že my sme pracovné listy inštrumentov nemali), aby videla kresby tak ako majú byt' správne otočené.

Spočiatku bola práca s premostovaním na dobrej úrovni, Sofia však len uvádzala príklady bez ohl’adu na riešený problém, postupne sa táto prekážka odbúrala.

\section{Graf 17 Kristiánko - impulzivita pri riešení úloh}

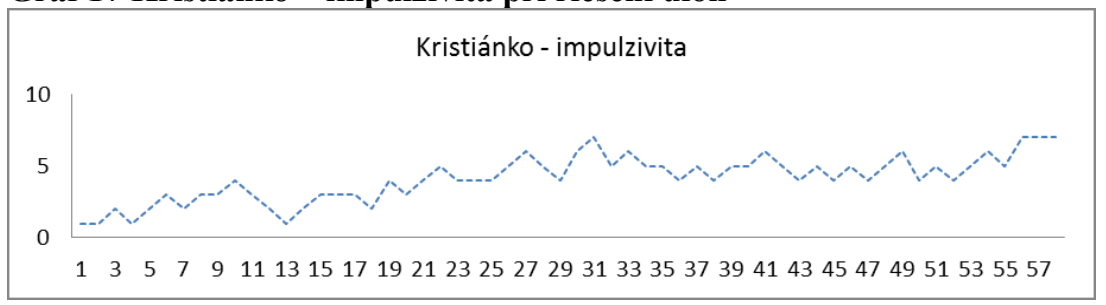

Slavonic Pedagogical Studies Journal, ISSN 1339-866o, Volume 5 Issue 1, February 2016 


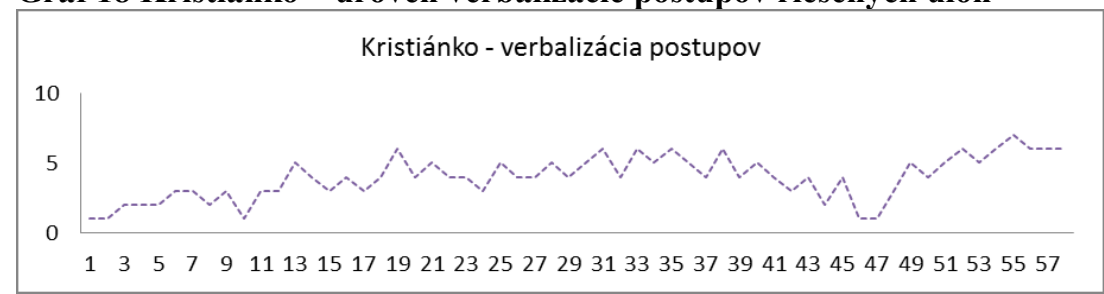

Graf 19 Kristiánko - prekonávanie problémov v percepčnej oblasti

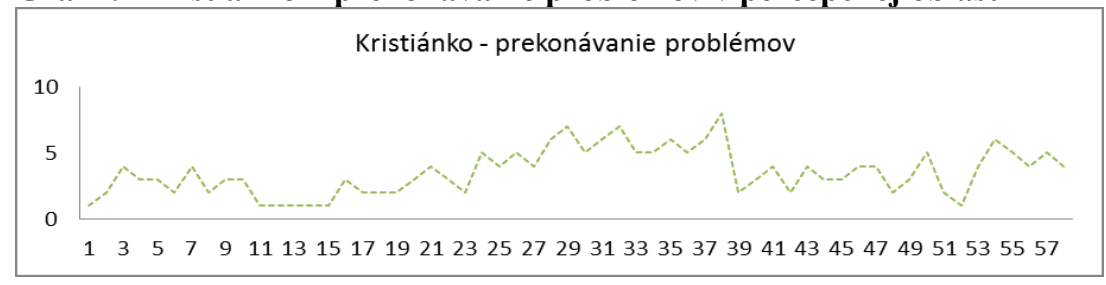

\section{Graf 20 Kristiánko - práca s premostením}

Kristiánko - práca s premostením

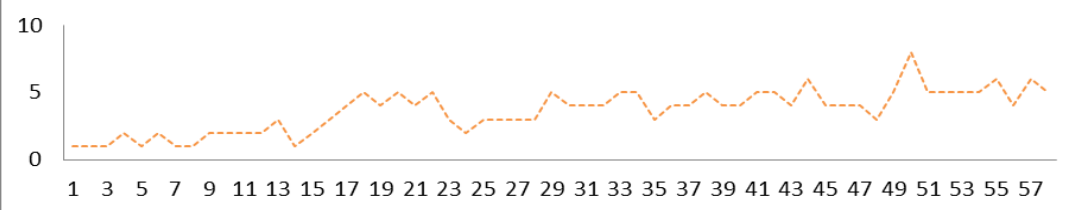

Kristiánko bol zo skupiny jediné diet’a, ktoré malo opätovne odložený nástup na povinnú školskú dochádzku. Kristiánko bol aj vzrastom najvyšší a preto zo začiatku mali deti pred ním rešpekt. Kristiánko však napriek týmto predstavám detí bol vel'mi kamarátsky. Deti si mysleli, že je vel'mi zlý, pretože podl'a nich pani učitel'ky na neho na školskom dvore stále kričia, nielen jeho pani učitel'ka, ale všetky čo sú na dvore. Kristiánko je vel'mi aktívne a zvedavé diet'a. Kládol vel'mi vel'a otázok a zvedavo čakal na odpoved'. Zaujímali ho však odpovede len na vlastné otázky a ked' nedostal hned' na ne odpoved', strácal záujem o spoločnú prácu.

V úvodných stretnutiach bol problém zaujat' jeho pozornost' na aktivity a úlohy, ktoré robila celá skupina. Ked' deti spoznali Kristiánka, že je priatel'ský a otvorený, tak sa Kristiánko viac cítil ako člen skupiny a nebol problém s jeho motiváciou.

Výrazné problémy mal Kristiánko s ovládaním svojej impulzivity. Pri práci $\mathrm{s}$ jednotlivými inštrumentmi často riešil úlohy pokusom a omylom, čím mal väčšinou nesprávne vyriešené úlohy, nakol'ko sme kládli dôraz na proces riešenia, kontrolu vlastnej práce, $\mathrm{v}$ prípade chýb bolo nevyhnutná ich identifikácia a následná oprava. Kristiánko tiež považoval za dôležité nájst' výsledné riešenie a nezaujímal sa o prácu popri inštrumentoch. Jednotlivé listy inštrumentov a škatula s predmetmi boli pre neho natol'ko lákavé, že prácu pri premost’ovaní, riešenie iných čiastkových úloh, či odvodzovanie vzt'ahov vnímal ako povinnost', bez ktorej nemôžeme postupovat' v práci, 
pretože sme mu to my neumožnili. Jednotlivé pojmy, ktoré sme pri práci s úlohami vyvodzovali si potom Kristiánko nezvnútornil, nevytvoril si predstavu o pojmoch a to mu potom spôsobovalo problém pri d’alšej práci. Ako vyplýva z grafov, vo všetkých zložkách dosahoval Kristiánko väčšinou podpriemerné hodnotenie. To znamená, že v priebehu celého školského roku mal nielen nevyrovnané výkony, ale ani nedosahovali potrebnú úroveň. Kristiánko pochádzal zo sociálne znevýhodneného prostredia a preto aj pri premost’ovaní a hl'adaní podobných situácií bol Kristiánko vel'mi znevýhodnený oproti svojim spolužiakom, nakol'ko $\mathrm{v}$ jeho rodinnom prostredí nemal vytvorené dostatočne rozvíjajúce prostredie. Jeho slovná zásoba bola stále na úrovni pät' - šest' ročných detí. Kristiánko mal zážitky zo spoločenských udalostí a akcií (divadlo, deň detí, oslava Mikuláša) len z prostredia materskej školy. Preto aj úroveň jeho premost'ovania bola ochudobnená o zážitky, ktoré iné deti zažili vo svojich rodinách.

Rovnako nevyrovnaný výkon bol v oblasti prekonávanie problémov. Kristiánko sa totiž vo svojom sociálnom prostredí často stretáva s nedôverou a nedostatkom motivácie.

\section{Graf 21 Radka- impulzivita pri riešení úloh}

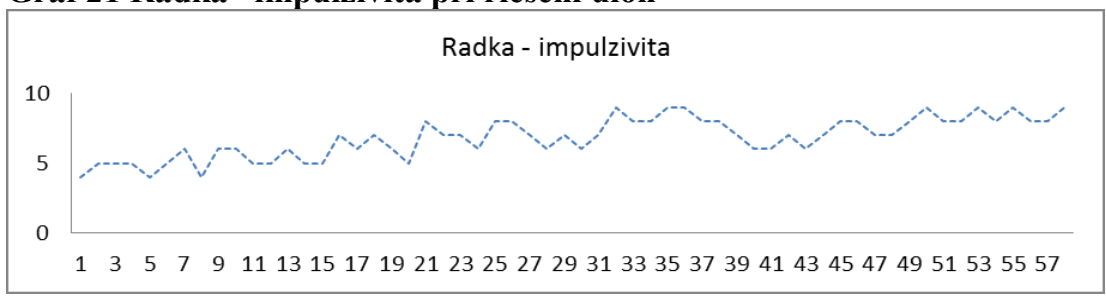

\section{Graf 22 Radka - úroveň verbalizácie postupov riešených úloh}

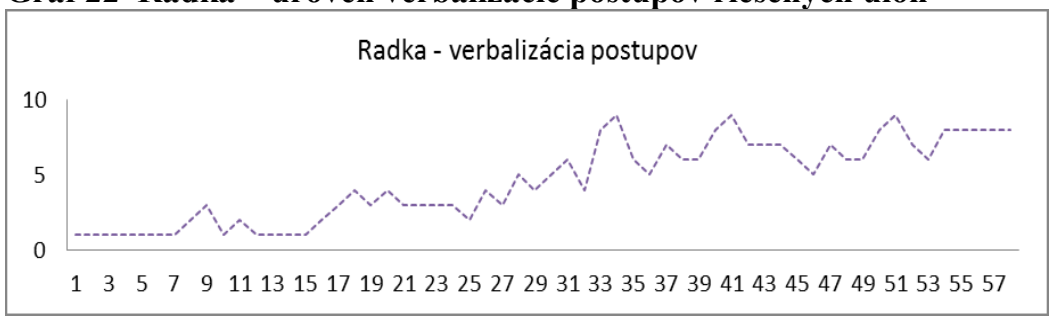

\section{Graf 23 Radka - prekonávanie problémov v percepčnej oblasti}

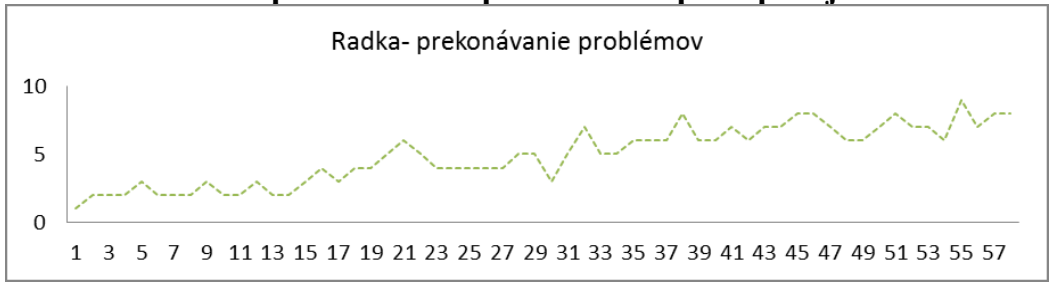

Slavonic Pedagogical Studies Journal, ISSN 1339-866o, Volume 5 Issue 1, February 2016 


\section{Graf 24 Radka - práca s premostením}

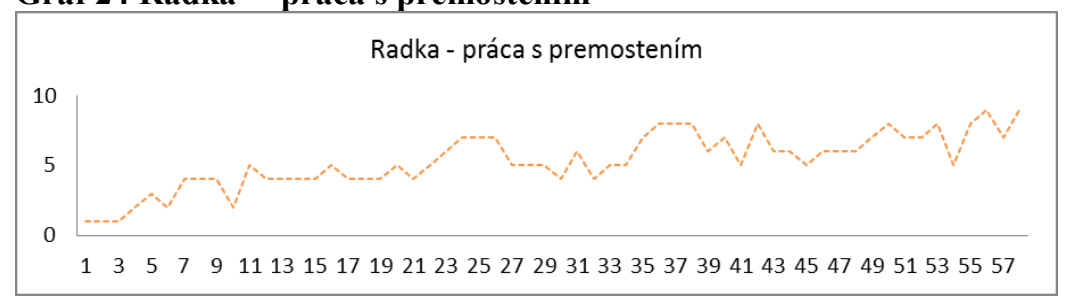

Radka urobila $\mathrm{v}$ priebehu účasti na programe inštrumentálneho obohacovania najvýraznejší pokrok. Radka bola na začiatku vel'mi utiahnutá a tichá. Už pri úvodnom testovaní sme si všimli, že je uzavretá, s det'mi vel'mi nekomunikovala. $\mathrm{V}$ tichosti sedela a čakala na inštrukcie. Jednotlivé úlohy $\mathrm{v}$ testoch vypracovávala, ale podl'a kresieb a odpovedí nevedela čo je jej úlohou. Na papier kreslila nezrozumitel'né obrazce, pretože videla, že aj ostatné deti kreslia. Na naše výzvy a podnecovanie $\mathrm{k}$ rozhovoru spočiatku nereagovala. Radka má strach z neznámych situácií a trvá jej dlhšie ako ostatným detom, kým sa danej situácii prispôsobí.

Radka zo začiatku pracovala samostatne, ale nekoncentrovane. Nezapájala sa do úloh. Zmena nastala, ked' sme sa spolu snažili o usporiadanú konverzáciu, ked' sme sa rozprávali o tom, že si nebudeme skákat' do reči. Už sme uviedli, že bol problém prekonat' u detí domnienku, že učitel' je $\mathrm{v}$ škole kvôli tomu, aby opravoval odpovede detí a rozhodoval, či je riešenie správne, alebo nie.

V priebehu práce sme sa snažili Radku povzbudzovat' k práci a až po našej viacnásobnej pochvale (približne po siedmych stretnutiach) Radka sama od seba začala reagovat' na proces riešenia bez toho, aby sme ju oslovili. Stále však čakala, ako budeme hodnotit' jej odpoved', či je správna, alebo nie.

$\mathrm{S}$ det'mi sme často mali problém, že aj ked' nám formálne hovorili rôzne situácie zo života kde sa stretli s riešenou problematikou, nevideli $\mathrm{v}$ nich význam a spojitost' so situáciou, prípadne, že sa situácia môže zmenit' a nami predpokladaná skutočnost' neplatí. Napríklad $v$ inštrumente usporiadanie bodov sa pracuje aj s tzv. nápovedami, ktorú sú vyjadrené farebne (farebne odlíšené body, čím sa riešenie úlohy zjednoduší). S det’mi sme sa rozprávali kedy je farba dôležitá a kedy na nej nezáleží (napr. na semafore je dôležité ktorá farba svieti, ale napríklad farba trička, ktoré si oblečiem nie je dôležité). Všetko však záleží od konkrétnej situácie, to znamená, že sú situácie, kedy je aj farba trička dôležitá (napr. ked' hráme futbal a sme rozdelení do tímov). Túto skutočnost' deti neprijímali a držali sa prvého tvrdenia, že nie je dôležitá farba trička. Súvisí to samozrejme aj $\mathrm{s}$ ich skúsenost’ami, nakol'ko v materskej škole futbal hrávajú, ale nie sú rozdelení do tímov. Našou úlohou nebolo učit' deti všetky situácie, ale deti majú odvodzovaním objavovat' nové informácie a poznatky, preto sme $\mathrm{v}$ danej situácii problém d’alej podrobnejšie nerozvíjali.

Po prekonaní nedôvery v nás a vo vlastné schopnosti sa Radka stala aktívnou členkou skupiny, zapájala sa do všetkých úloh a nebála sa hovorit' o riešení nahlas, čím sa výrazne zlepšil jej výkon vo všetkých zložkách. 
Z prezentovaných výsledkov vyplýva, že u všetkých detí zaradených do experimentálnej skupiny sme zaznamenali pozitívne zmeny vo všetkých sledovaných faktoroch.

Vzácna zhoda nastala $\mathrm{v}$ počte stretnutí, na ktorých sa deti zúčastnili. Vyhodnotili sme celkom 57 stretnutí z celkového počtu. V priebehu školského roka sa stalo, že nie všetky deti boli účastné každého stretnutia, čo je samozrejmé. Môžem konštatovat', že pri plánovaní empirického overovania programu v podmienkach našich škôl sme sa obávali, že dochádzka detí do materskej školy bude nepravidelná a bude náročné s programom pracovat'. Naše obavy sa nenaplnili najmä vd'aka rodičom, ktorí zodpovedne pristupovali k spolupráci s nami.

\section{Záver}

V zmysle naplnenia stanovených ciel'ov sme sa pokúsili prostredníctvom vybraného programu kognitívnej edukácie zistit' vplyv aplikácie programu na rozvoj kognitívnych funkcií detí. Program inštrumentálneho obohacovania R. Feuersteina - základný sme aplikovali pri práci s det’mi s odloženou školskou dochádzkou, aby sme tak predišli prehíbeniu limitov v snahe pripravit' deti na úspešné zvládnutie a napíňanie požiadaviek školy a spoločnosti. Program inštrumentálneho obohacovania R. Feuersteina bol overovaný mnohými výskumami a jeho efektivita je nesporná. My sme sa však zamerali na hladanie možnosti jeho uplatnenia nielen v oblasti rozvoja kognitívnych funkcií, prípadne nápravy deficitných funkcií, ale rovnako tak $\mathrm{v}$ transfere do emocionálnych a sociálnych schopností jednotlivca, aby bol plnohodnotne pripravený na zvládnutie role žiaka, role člena spoločnosti.

Rozvíjajúci program výchovy a vzdelávania detí s odloženou povinnou školskou dochádzkou v materských školách (2005) ako podporný program $\mathrm{k}$ Programu výchovy a vzdelávania detí $\mathrm{v}$ materských školách je $\mathrm{v}$ našich podmienkach platný od roku 2005. V praxi však nie je využívaný (mnohé učitel'ky nevedia, že existuje). Stavia na rovnakých princípoch ako samotný vzdelávací program. Domnievame sa, že očakávanie jeho úspešnosti je obmedzené tým, že neponúka alternatívy. Ak diet’a navštevovalo materskú školu a prejavili sa u neho bariéry v pripravenosti na vstup do školy, je potrebné mu ich ponúknut' a naplnit' ich. Nie opakovaním, ale zmenou prístupu, navrhnutím alternatívy. Nám sa podarilo výskumným šetrením preukázat', že program inštrumentálneho obohacovania vzhl'adom na svoj intervenčný charakter je vhodným nástrojom ako pripravovat' deti na vstup do školy.

\section{Bibliographic references}

BIROVA, J. 2013. O teoretickych definiciach viacjazycnych a plurikulturnych pristupov $\mathrm{k}$ vyucovaniu cudzich jazykov. In Xlinguae, Vol.6, N.2, pp. 23-42. ISSN 1337-8384.

BURDEN, R. 1987. Feuerstein's Instrumental Enrichment Programme: Important issues in research and evaluation. In European Journal of Psychology of Education. Volume 2, N. 1, pp. 3-16. Available online: http://www.springerlink.com/ content/vv56765255 290252.

Slavonic Pedagogical Studies Journal, ISSN 1339-866o, Volume 5 Issue 1, February 2016 
DUCHOVICOVA, J. 2011. Kognitivna edukacia a sprostredkovane ucenie. In Kolektiv autorov. 2011. Vybrane kapitoly z didaktiky pedagogiky a socialnej pedagogiky. Nitra : PF UKF. ISBN 9788080948573.

DUCHOVICOVA, J. 2013. Ponatie diversity v skolskom prostredi a aspekty pedagogickej diagnostiky $\mathrm{v}$ kontexte ziackej diversity. In Duchovicova, J. et al. Diverzita skolskej populacie ako objekt pedagogickej vedy. Nitra: PF UKF. pp. 20-95. ISBN 9788055805283.

DUCHOVICOVA, J. - GUNISOVA, D. 2015. Strukturovanie uciva ucitelom a konceptualizacia poznatkov ziakov. In Slavonic Pedagogical Studies Journal. The Scientific Educational Journal, vol 4, n.1, pp. 33-49, ISSN 13398660.

FALIK, L.H. 2006. Uspesna inkluze zaku se specialnimi potrebami v beznem edukativnim prostredi: role poradenstvi a odborne intervence. In POKORNA, V. 2006. Inkluzivni a kognitivni edukace. Prague: PF UK. pp. 44-51. ISBN 807290-258-X.

FALIK, L.H. 2009. Using Mediated Learning Experience Parametres to Change Children's Behaviour: Techniques for Parents and Childcare Providers. Available online: www.icelp.org/files/research /ParentMednPprFalik.pdf.

FEUERSTEIN, R. 2005. Early Detection: Blessing or Curse. Available online: http://www.icelp.org/files/research/EarlyDetection.pdf.

FEUERSTEIN, R. 2006. Podpora inkluzivniho a kognitivniho vyucovani ve skolach. In POKORNA, V. Inkluzivni a kognitivni edukace. Prague: UK. pp. 10-20. ISBN 807290-258-X

FEUERSTEIN, R - KLEIN, P. S. - TANNENBAUM, A. J. 1994. Mediated learning experience (MLE): theoretical, psychosocial and learning implications. Tel Aviv: Freund Publishing House Ltd. ISBN 965294-085-2.

FEUERSTEIN, R. - RAND, Y. - HOFFMAN, M.B. - MILLER, R. 1980. Instrumental Enrichment: An intervention program for cognitive modifiability. Baltimore, MD: UPP. ISBN 0-673-24600-0.

FLYNN, J.R. 1987. Massive gais in 14 nations: What IQ tests really measure. In Psychological Bulletin, 101, pp. 171-191.

HOLLA, K. - KURINCOVA, V. 2013. Manifestations of Aggressive Behaviour in Pupils - Theoretical Views and Research Findings. In The New Educational Review. Vol. 34, No. 4. pp. 111-122. ISSN 1732-6729.

HORVATHOVA, B. - REID, E. 2013. Parents' Reflections on the Education of Gifted Children in Slovakia. In Xlinguae Journal, Vol. 6, N. 1, p. 30-49. ISSN 1337-8384.

KAHN, R. - STEMLER, S. - BERCHIN-WEISS, J. 2009. Enhancing Parent Participation in Early Intervention Through Tools That Support Mediated Learning. In Journal of Cognitive Education and Psychology. Volume 8, Number 3, pp. 269 - 288. ISSN 1945-8959.

KARPOV, Y. V. - TZURIEL, D. 2009. Dynamic Assessment: Progress, Problems, and Prospects. In Journal of Cognitive Education and Psychology. Volume 8, Number 3, pp. 228-238. ISSN 1945-8959. 
KOMORA, J. - POLAKOVICOVA, R. 2013. Diverzita skolskej triedy v kontexte inkluzivneho vzdelavania ziackej populacie. Nitra: UKF. ISBN 978-80-558-0379-1.

KOZULIN, A. 2009. New Reference Points for Dynamic Assessment (DA): A Commentary on Karpov and Tzuriel. In Journal of Cognitive Education and Psychology. Volume 8, Number 3, pp. 242 - 246. ISSN 1945-8959.

LURIJA, A.R. 1961. The role of speech in the gregulation of normal and abnormal behaviour. London: Pergaon press.

MALKOVA, G. 2008. Zprostredkovane uceni. Prague: Togga. ISBN 97880-7367-585-1.

MALOVECKY, M. 2014. Lingvisticke komponenty hladania metody $\mathrm{v}$ kontrastivnej jazykovede. Hladanie metody $\mathrm{v}$ kontrastivnej lingvistike Bratislava: Univerzita Komenského, pp. 12-32. ISBN 978-80-223-3772-4.

POKORNA, V. 2006. Inkluzivni a kognitivni edukace. Prague: PF UK. ISBN 807290-258-X

POKORNA, V. 2010b. Interny material kurzu FIE Zakladny I. Hlohovec.

POKORNA, V. 2010c. Teorie a naprava vyvojovych poruch uceni a chovani. Prague: Portal. ISBN 978-80-7367-817-3.

PISONOVA, M. 2016. Philosophical Explication of Requirements on the Process of Education - Novelty or Relic? In XLinguae Journal, Volume 9 Issue 1, January, pp. 83-90. ISSN 1337-8384.

SLEZAKOVA, T. 2008. Preparation of a Disabled Child for Entering the School in Conditions of an Ordinary Nursery School. In The New Educational Review. Vol. 15, No. 2, pp. 129-135. ISSN 1732-6729.

STERNBERG, R. J. - POWEL, J. S. 1983. Comprehending verbal comprehension. American Psychologist, 38, pp. 878-893.

Program vychovy a vzdelavania deti $v$ materskych skolach. Available online:http://www.statpedu.sk/files/documents/svp/ms/program_vychovy_ materske_skoly.pdf.

Rozvijajuci program vychovy a vzdelavania deti s odlozenou povinnou skolskou dochadzkou $\mathrm{v}$ materskych skolach. Available online: http://www.statpedu.sk/files/documents/svp/ms/rozvijajuci_program.pdf.

PaedDr. Zuzana Babulicová, PhD.

Department of Pedagogy

Faculty of Education

Constantine the Philosopher University

Dražovská cesta 4, 94901 Nitra

Slovakia

zbabulicova@ukf.sk 